\title{
Epigenetic regulation of caloric restriction in aging
}

Yuanyuan $\mathrm{Li}^{1,3^{*}}$, Michael Daniel ${ }^{1}$ and Trygve O Tollefsbol ${ }^{1,2,3,4,5}$

\begin{abstract}
The molecular mechanisms of aging are the subject of much research and have facilitated potential interventions to delay aging and aging-related degenerative diseases in humans. The aging process is frequently affected by environmental factors, and caloric restriction is by far the most effective and established environmental manipulation for extending lifespan in various animal models. However, the precise mechanisms by which caloric restriction affects lifespan are still not clear. Epigenetic mechanisms have recently been recognized as major contributors to nutrition-related longevity and aging control. Two primary epigenetic codes, DNA methylation and histone modification, are believed to dynamically influence chromatin structure, resulting in expression changes of relevant genes. In this review, we assess the current advances in epigenetic regulation in response to caloric restriction and how this affects cellular senescence, aging and potential extension of a healthy lifespan in humans. Enhanced understanding of the important role of epigenetics in the control of the aging process through caloric restriction may lead to clinical advances in the prevention and therapy of human aging-associated diseases.
\end{abstract}

Keywords: caloric restriction, epigenetic, aging

\section{Introduction}

Aging and its direct consequences, such as degenerative diseases and even death, are inevitable; however, scientific advances in understanding basic aging mechanisms have made it much more feasible to postpone aging processes and to increase the human lifespan using clinical

\footnotetext{
* Correspondence: lyy@uab.edu

'Department of Biology, University of Alabama at Birmingham, 1300

University Boulevard, Birmingham, AL 35294, USA

Full list of author information is available at the end of the article
}

approaches. Current studies using model organisms indicate that aging processes can be manipulated by many interacting factors which include, but are not limited to, geneticnutritional and pharmacological interventions [1-3]. Studies of monozygotic twins, who share the same genotype and often present many phenotypic differences [4-7], indicate that external environmental factors contribute to interindividual differences such as susceptibility to disease and the potential to live longer.

Dietary control, as a major environmental factor, has a profound effect on many aspects of health, including aging, and caloric restriction (CR) is by far the most effective environmental manipulation that can extend maximum lifespan in many different species $[8,9]$. In fact, the remarkable effect of CR on aging was first defined in experimental animal models in which McCay et al. [10] discovered that rats fed a calorie-restricted diet lived longer than control rats fed a regular diet. Since then, numerous research findings have revealed effects of CR on lifespan interference among diverse, but not all eukaryotes, including yeast, worms, flies, fish and even mammals [11-13]. In most rodent CR studies, the limitation of total calories derived from carbohydrates, fats or proteins to a level $25 \%$ to $60 \%$ below that of control animals fed ad libitum, while containing all essential nutrients [14-16], can result in a significant lifespan extension in 50\% of rodents [17-21]. In addition to increasing lifespan in rodents, $C R$ has also been shown to delay a wide range of aging-associated diseases, such as cancer, diabetes, atherosclerosis, cardiovascular diseases and neurodegenerative diseases in higher mammals, such as nonhuman primates and humans [13,22-24] (Table 1). The incidence of disease increases with age and is a fundamental contributor to mortality. Thus, CR may affect aging processes by favorably influencing broad aspects of human health.

Numerous studies suggest that the effects of CR in the prevention of the onset of many aging-related degenerative diseases occur through various molecular mechanisms, including reduction of oxidative stress or 
Table 1 Summary of aging-related diseases affected by caloric restriction in experimental animal models and clinical trials ${ }^{a}$

\begin{tabular}{|c|c|c|c|c|c|}
\hline Diseases & Findings & Rodents & $\begin{array}{l}\text { Nonhuman } \\
\text { primates }\end{array}$ & Humans & References \\
\hline Cancer & $\begin{array}{l}\text { CR prevents a broad range of cancer incidences, including breast and } \\
\text { gastrointestinal cancer. }\end{array}$ & Y & Y & $\mathrm{Y} / ?$ & {$[17,13,23]$} \\
\hline Diabetes & CR improves glucose homeostasis and prevents diabetes. & Y & Y & Y & {$[18,13,23,24]$} \\
\hline $\begin{array}{l}\text { Cardiovascular } \\
\text { diseases }\end{array}$ & $\begin{array}{l}\text { CR lowers blood pressure and favorably alters lipid profile, resulting in } \\
\text { significantly reducing the risk of cardiovascular disease and related } \\
\text { complications. }\end{array}$ & Y & Y & Y & {$[19,13,22-24]$} \\
\hline $\begin{array}{l}\text { Neurodegenerative } \\
\text { diseases }\end{array}$ & $\begin{array}{l}\text { CR reduces aging-associated neuronal loss and neurodegenerative disorders } \\
\text { such as Parkinson's disease and Alzheimer's disease. }\end{array}$ & Y & Y & $Y / ?$ & {$[20,13,23]$} \\
\hline $\begin{array}{l}\text { Immune } \\
\text { deficiencies }\end{array}$ & CR delays the onset of T-lymphocyte-dependent autoimmune diseases. & Y & $Y / ?$ & $Y / ?$ & {$[21]$} \\
\hline
\end{tabular}

${ }^{\mathrm{a}} \mathrm{CR}$, caloric restriction; $\mathrm{Y}, \mathrm{CR}$ has effects on relevant physiological changes; $\mathrm{Y} /$ ?, not resolved or not reported.

regulation of metabolic pathways during the progression of aging $[14,25,26]$. However, the precise mechanisms of CR-induced longevity are not very well understood. Recently, epigenetic mechanisms have received considerable attention due to the unique role of interactions with multiple nutritional factors and the aging processes. Epigenetic control is believed to dynamically regulate gene expression by mechanisms other than changes in the DNA sequence. This primarily affects two epigenetic codes: DNA methylation and histone modification [27-29]. Recent evidence suggests that DNA methylation status changes in specific gene loci may play an essential role in CR-dependent aging postponement and longevity [30,31]. More concrete evidence has emerged, most notably the discovery of silent mating type information regulation 2 homolog 1 (Sirtuin 1), a nicotinamide adenine dinucleotide $\left(\mathrm{NAD}^{+}\right)$-dependent histone deacetylase (HDAC), since Sirtuin 1 activity has been linked to the control of lifespan in response to CR both in vivo and in vitro [32-36]. Although studies of the characterization and function of epigenetic modifications in CR-associated longevity are just emerging, a better understanding of this complex interaction provides promising clinical opportunities for the prevention of human aging and degenerative diseases that often accompany the aging process.

\section{DNA methylation affects aging during caloric restriction}

DNA methylation is one of the most important epigenetic modifications. It provides a stable and heritable component of epigenetic regulation. DNA methylation primarily occurs on cytosine residues of CpG dinucleotides, which are frequently clustered into $\mathrm{CpG}$ islands at the regulatory sites of gene promoter regions. The amount of DNA methylation in a gene control region generally inversely correlates with gene activation $[37,38]$. The methyl groups on CpG dinucleotides can recruit multiple transcriptional complex proteins, including methylation-sensitive transcription factors and methyl-binding proteins that are often associated with gene silencing [39]. Therefore, DNA methylation plays an important role in the regulation of gene expression, maintenance of DNA integrity and stability in many biological processes, such as genomic imprinting, normal development, cell proliferation and aging [40-42]. The patterns of DNA methylation are dynamically mediated by at least three independent DNA methyltransferases (DNMTs): DNMT1, DNMT3a and DNMT3b. DNMT1 performs a maintenance function during cell division, while DNMT3a and DNMT3b act as de novo methyltransferases after DNA replication by adding a methyl moiety to the cytosine of CpG dinucleotides that have not previously been methylated [43-47].

During aging processes, there is a progressively reduced capability for homeostasis and loss of chromatin integrity, predominantly due to aberrant gene expression [48]. DNA methylation regulation plays a crucial role during aging processes. Age causes a dramatic change in the distribution of 5-methylcytosine (the product of DNA methylation) across the genome. This leads to a decrease in global DNA methylation [49-54]. Although genome-wide levels of methylation decrease with aging, the promoter regions of many specific genes tend to switch from unmethylated to methylated status, resulting in gene silencing, which may include promoters of several tumor- and/or agingrelated genes, such as RUNX3 and TIG1 [53,55] (Table $2)$. These findings suggest an essential role of agingassociated DNA methylation changes in the regulation of aging-related diseases such as cancer.

The evidence suggests that the biological effects of CR are closely related to chromatin function [56]. In fact, acting as an important environmental intervention, CR is speculated to exert its aging-delaying effect through its capacity to increase genomic stability. Reversal of aberrant DNA methylation during aging is believed to be the most effective mechanism for CR to maintain 
Table 2 Selected genes regulated by epigenetic factors during caloric restriction ${ }^{a}$

\begin{tabular}{|c|c|c|c|c|}
\hline Genes & Gene functions in aging & Epigenetic regulation & CR effects & References \\
\hline p16 INK4a & $\begin{array}{l}\text { Tumor suppressor gene that inhibits cell cycle and } \\
\text { accumulates during aging }\end{array}$ & $\begin{array}{l}\text { DNA methylation, histone acetylation } \\
\text { (mediated by SIRT1 and HDAC1) and histone } \\
\text { methylation }\end{array}$ & Downregulation & {$[31,84]$} \\
\hline p53 & $\begin{array}{l}\text { Tumor suppressor gene that induces cell cycle arrest, } \\
\text { apoptosis and senescence; increased p53 promotes aging }\end{array}$ & Histone acetylation (mediated by SIRT1) & Downregulation & {$[88-90]$} \\
\hline H-ras & Oncogene that accelerates aging & DNA methylation & Downregulation & [30] \\
\hline RUNX3 & $\begin{array}{l}\text { Transcription factor that plays important roles in } \\
\text { development; increases methylation with aging }\end{array}$ & DNA methylation & Up regulation & {$[53,55]$} \\
\hline FOXO & $\begin{array}{l}\text { Forkhead transcription factors that control various biological } \\
\text { functions and involve SIRT1-related longevity }\end{array}$ & Histone acetylation (mediated by SIRT1) & Downregulation & {$[91,92]$} \\
\hline Ku>0 & $\begin{array}{l}\text { A component of the NHEJ pathway for DSB repair that } \\
\text { regulates apoptosis and DNA repair during aging }\end{array}$ & Histone acetylation (mediated by SIRT1) & Downregulation & {$[99,100]$} \\
\hline$P G C-1 \alpha$ & $\begin{array}{l}\text { Regulates mitochondrial function and glucose homeostasis } \\
\text { and interacts with SIRT1 to regulate glucose metabolism } \\
\text { during CR }\end{array}$ & Histone acetylation (mediated by SIRT1) & Upregulation & {$[34,83,93,94]$} \\
\hline hTERT & $\begin{array}{l}\text { Tumor promoting gene; increased } h T E R T \text { expression is } \\
\text { correlated with telomerase activation and aging delay }\end{array}$ & $\begin{array}{l}\text { Histone acetylation (mediated by HDAC1) } \\
\text { and histone methylation }\end{array}$ & Upregulation & [31] \\
\hline
\end{tabular}

${ }^{a} \mathrm{CR}$, caloric restriction; $h T E R T$, human telomerase reverse transcriptase; HDAC1, histone deacetylase 1; SIRT1, Sirtuin (silent mating type information regulation 2 homolog) 1; NHEJ, non-homologous end joining; DSB, DNA double-strand break.

chromatin function and subsequently influence aging processes.

As discussed previously, two major changes in DNA methylation occur during aging progression. These changes involve globally decreased but locally increased DNA methylation status. Interestingly, CR is likely to recover these aging-induced aberrant DNA methylation patterns, but by specific loci control rather than globally [57] (Figure 1). Studies of the comparison of DNA methylation levels in pancreatic acinar cells between CR-fed rats and control rats fed ad libitum suggest that CR increased the methylation level of proto-oncogenes such as Ras [30] (Table 2). A hypermethylated gene promoter will often be recognized by transcriptional repressor complexes, leading to silencing the expression of these oncogenes, which contributes to the effects of CR on cancer prevention. Although the majority of $C R$ research has been based on experimental animal studies, we have established an in vitro mammalian cellular system to mimic CR-controlled longevity by the reduction of glucose, the main caloric resource in cell culture medium [31]. In our current studies of human cells, DNA hypermethylation of an $E 2 F-1$ binding site was found in the promoter of the $p 16^{I N K 4 a}$ gene, an important tumor suppressor and aging-associated gene. This DNA hypermethylation of the E2F-1 binding site blocks access of $E 2 F-1$ (an active transcription factor of $\left.p 16^{I N K 4 a}\right)$ to the $p 16^{I N K 4 a}$ promoter, resulting in $p 16^{I N K 4 a}$ downregulation, which contributes to CRinduced lifespan extension (Table 2 and Figure 1). In this regard, there is a strong tendency for the DNA methylation pathway to predominately control key cancer-related genes during $\mathrm{CR}$, suggesting a close connection between aging and cancer.
On the basis of the preceding discussion, we confirm that DNMTs play a crucial role in maintaining or rewriting DNA methylation profiles. Consistently, DNMT1 activity is significantly elevated in response to $\mathrm{CR}$ to correct the decreased methylation level during aging [31]. Further studies have also indicated that CRcaused Dnmt3a level changes in the mouse hippocampus may benefit mouse brain function during aging [58]. Both DNMT1 and DNMT3b play a critical role in regulating cellular senescence in human stem cells [59]. Therefore, it is highly possible that CR modulates DNA methylation, depending on expression levels and/or enzymatic activities of individual DNMTs (Figure 1).

Because of the critical roles of DNMTs in the control of aging and aging-associated diseases such as cancer and DNMT inhibitors such as azacitidine (5-azacytidine) and decitabine (5-aza-2'-deoxycytidine) have been widely used for cancer treatment in both experimental studies and clinical trials [60] (Table 3). Moreover, some bioactive food components with DNMT inhibition properties, such as green tea polyphenols and soybean genistein, have shown cancer prevention and inhibition activities by reducing DNA hypermethylation of key cancer-causing genes [61-63] (Table 3). These are important and encouraging findings that imply the potential translation of these bioactive dietary compounds into intervention targets and strategies for the prevention and treatment of human cancer.

Since restricted caloric intake induces a series of metabolic responses to nutrition deficiency, effective regulation of metabolic processes to adapt to this change could be another important mechanism underlying the effect of $C R$ on longevity. One approach to interpreting $\mathrm{CR}$ in the regulation of metabolic pathways 


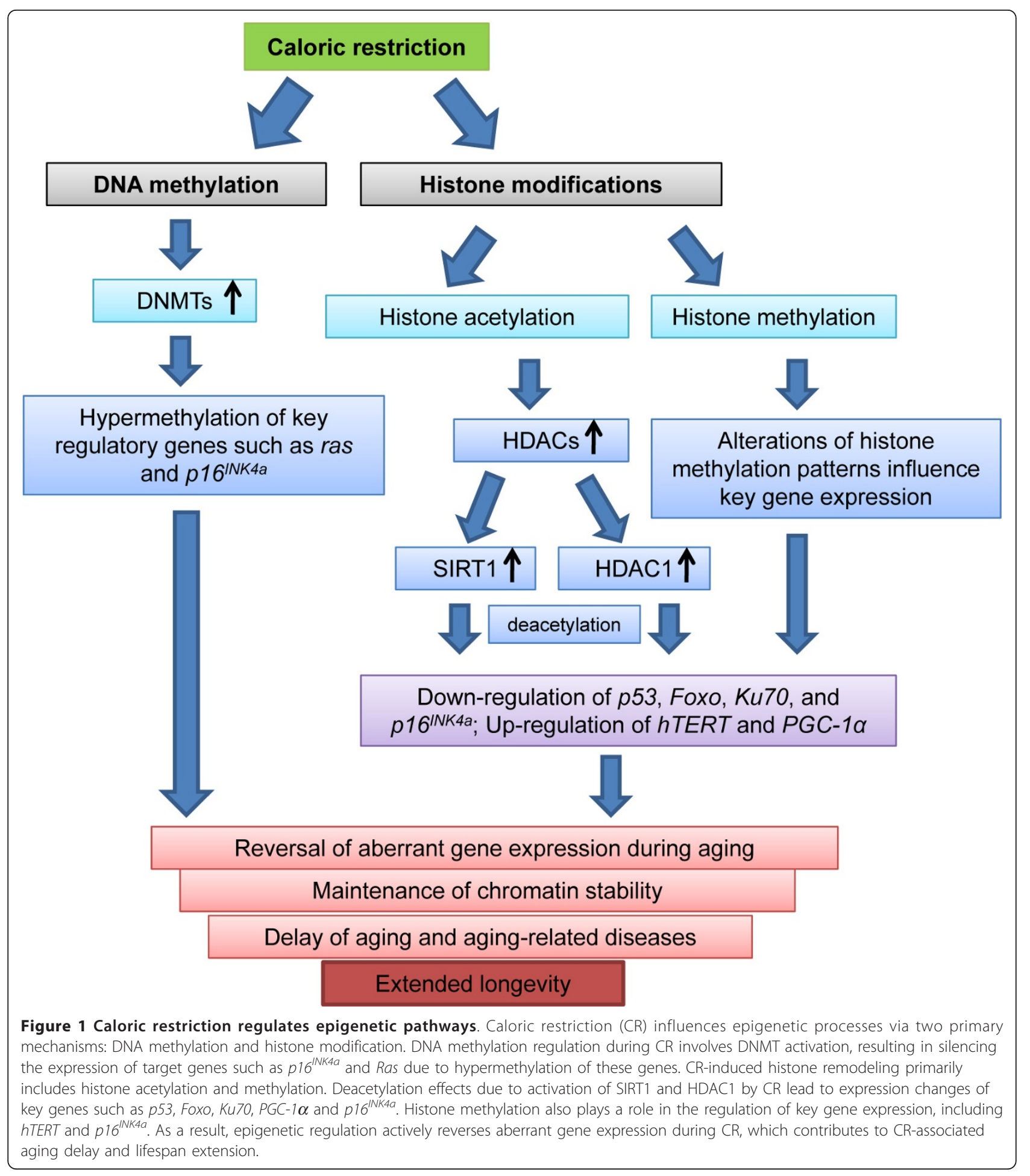

is through interventions to treat human obesity, which has become an important public health issue in recent years. Obesity is a common metabolic disorder characterized by excessively accumulated body fat and is closely related to a series of human diseases, including diabetes, hypertension, dyslipidemia, cardiovascular complications and even cancer, which are recognized causes of accelerated aging [64]. Therefore, obesity prevention could be a key underlying factor in the antiaging effects of CR. Because of its substantial and promising effects in promoting weight loss, CR is widely used in clinical weight control intervention [65]. Current 
Table 3 Epigenetic clinical trials for aging-related degenerative diseases ${ }^{a}$

\begin{tabular}{|c|c|c|c|c|}
\hline Drugs & $\begin{array}{l}\text { Epigenetic } \\
\text { effect }\end{array}$ & Description & Clinical trials & References \\
\hline Azacitidine & DNMT inhibitors & $\begin{array}{l}\text { 5-azacytidine; a chemical analogue of cytidine } \\
\text { that affects DNA methylation as a false } \\
\text { substrate }\end{array}$ & $\begin{array}{l}\text { Phases I, II and III: myelodysplastic syndromes } \\
\text { such as leukemia }\end{array}$ & [60] \\
\hline Decitabine & DNMT inhibitors & $\begin{array}{l}\text { 5-aza-2'-deoxycytidine, a chemical analogue of } \\
\text { cytidine that affects DNA methylation as a false } \\
\text { substrate }\end{array}$ & $\begin{array}{l}\text { Phases I, II and III: myelodysplastic syndromes } \\
\text { such as leukemia, cervical, and non-small-cell } \\
\text { lung cancer }\end{array}$ & [60] \\
\hline Depsipeptide & HDAC inhibitors & Cyclic tetrapeptide & $\begin{array}{l}\text { Phases I and II: hematological tumors such as } \\
\text { leukemia and lymphoma }\end{array}$ & {$[78,79]$} \\
\hline Phenylbutyrate & HDAC inhibitors & Aliphatic acid & $\begin{array}{l}\text { Phases I and II: hematological tumors such as } \\
\text { leukemia and lymphoma and colorectal cancer }\end{array}$ & {$[78,79]$} \\
\hline Valproic acid & HDAC inhibitors & Aliphatic acid & $\begin{array}{l}\text { Phase I: hematological tumors such as } \\
\text { leukemia and lymphoma }\end{array}$ & {$[78,79]$} \\
\hline $\begin{array}{l}\text { Suberoylanilide } \\
\text { hydroxamic } \\
\text { acid }\end{array}$ & HDAC inhibitors & Hydroxamic acid & $\begin{array}{l}\text { Phases I and II: hematological tumors, such as } \\
\text { leukemia and lymphoma, solid tumors }\end{array}$ & {$[78,79]$} \\
\hline Resveratrol & SIRT1 activator & $\begin{array}{l}\text { A natural compound enriched in grapes and } \\
\text { red wine }\end{array}$ & $\begin{array}{l}\text { Phase I and II: diabetes, obesity, Alzheimer's } \\
\text { disease and cancers }\end{array}$ & {$[118,119]$} \\
\hline Genistein & $\begin{array}{l}\text { Inhibitor of both } \\
\text { DNMTs and } \\
\text { HDACs }\end{array}$ & $\begin{array}{l}\text { Active epigenetic diet found in soybean } \\
\text { products }\end{array}$ & Preclinical: diabetes and cancer & {$[61,63,122,123]$} \\
\hline EGCG & $\begin{array}{l}\text { Inhibitor of both } \\
\text { DNMTs and } \\
\text { HDACs }\end{array}$ & $\begin{array}{l}\text { Active epigenetic dietary compound enriched } \\
\text { in green tea }\end{array}$ & $\begin{array}{l}\text { Phase I: diabetes, cardiovascular disease and } \\
\text { cancer }\end{array}$ & {$[61,62,124,125]$} \\
\hline Sulforaphane & HDAC inhibitor & $\begin{array}{l}\text { Active epigenetic dietary compound enriched } \\
\text { in broccoli sprouts }\end{array}$ & Preclinical & {$[80,121]$} \\
\hline
\end{tabular}

DDNMT, DNA methyltransferase; HDAC, histone deacetylase; SIRT1, Sirtuin (silent mating type information regulation 2 homolog) 1; EGCG, epigallocatechin gallate.

studies focusing on short-term CR interventions in obese human subjects revealed that hypocaloric diets cause DNA methylation changes in specific loci, such as ATP10A, WT1 and TNF- $\alpha$, which could be used as early indicators of a response to the metabolic effects and as predictors of outcomes in weight-loss programs [66-68]. Although further CR studies have identified a pool of DNA methylation-controlled candidate genes that may be closely correlated with metabolic pathways, widespread methylation changes on numerous gene loci that facilitate $C R$ in reprogramming the DNA methylation profile may also explain a powerful and universal effect of CR in influencing different aspects of human health. Thus, better understanding the functions of these DNA methylation-sensitive genes may contribute not only to optimizing personal weight-loss plans, but more important, to developing a novel application in slowing down of aging processes and the prevention of aging-related diseases.

Surprisingly few studies have investigated genomewide alterations in DNA methylation profiles in CRinduced longevity using in vivo or in vitro models. Thus, the complete methylation-regulated pathways and target genes that may be responsible for CR-induced longevity remain unknown. Further investigations in this particular area show promising prospects in developing novel clinical preventative or therapeutic approaches to agingrelated degenerative diseases.

\section{Effects of histone remodeling in control of aging during caloric restriction}

Histone modifications affect the basic structure of the chromatin unit, the nucleosome. The nucleosome consists of $146 \mathrm{bp}$ of DNA wrapped around an octamer of histones (two copies of $\mathrm{H} 2 \mathrm{~A}, \mathrm{H} 2 \mathrm{~B}, \mathrm{H} 3$ and $\mathrm{H} 4$ monomers) [69]. In most cases, histone remodeling occurs at the $\mathrm{N}$-terminal group of lysine $(\mathrm{K})$ residues in histones by diverse modification patterns such as acetylation, methylation, ubiquitination and ADP ribosylation, among which histone acetylation or deacetylation changes are considered to be the most prevalent mechanisms of histone modifications [27]. Histone modifications are associated with both gene activation and gene repression. The combination of modifications within histone tails directly changes nucleosome configuration and results in the status of chromatin switching to either a compacted status (tight-close) or a relaxed status (loose-open) [70]. Therefore, histone modifications determine the level of openness of chromatin and thus the degree of gene activity within a certain DNA region. For example, a deacetylated histone lysine residue has the positive charge, which attracts the negatively 
charged DNA strand producing a compact chromatin state that is associated with transcriptional repression. By contrast, the modification of histone acetylation removes the positive charge and results in an open chromatin structure, which leads to active transcription (Figure 2).

\section{Histone acetylation and deacetylation}

Histone acetylation and deacetylation processes are catalyzed by specific enzymes called histone acetyltransferases (HATs) and HDACs, respectively [71,72] (Figure 2 ). At least four classes of the HDAC family have been identified: class I HDACs (HDAC1, HDAC2, HDAC3 and HDAC8) are most closely related to the yeast Rpd3 HDAC; class II HDACs (HDAC4, HDAC5, HDAC6, HDAC7, HDAC9 and HDAC10) share homology domains with the yeast enzyme Hda1; class III HDACs including Sirtuins 1, 2, 3, 4, 5, 6 and 7 are homologues of the yeast Sir2; and HDAC11 is the only member of class IV HDACs and closely related to the class I HDACs.
In addition to their deacetylation function, HDACs are believed to participate in the regulation of many cellular functions and gene expression through interactions with hundreds of different transcription factors [71,73]. It has also been reported that HDAC activity is increased during CR, suggesting that global deacetylation may be a protective mechanism against nutrition stress and may influence the aging processes [31].

We have found that altered binding enrichment of HDAC1, such as on the promoter regions of the $p 16^{I N K 4 a}$ and human telomerase reverse transcriptase (hTERT) genes, the latter of which is a key determinant of telomerase activity closely associated with aging regulation, leads to beneficial expression changes of these two genes and contributes to longevity under CR conditions (Figure 1 and Table 2) [31,74,75]. Therefore, remarkable roles of the HDAC family in regulation of aging during CR highlight the potential application of related epigenetic drugs or clinical strategies in aging and aging-related diseases.

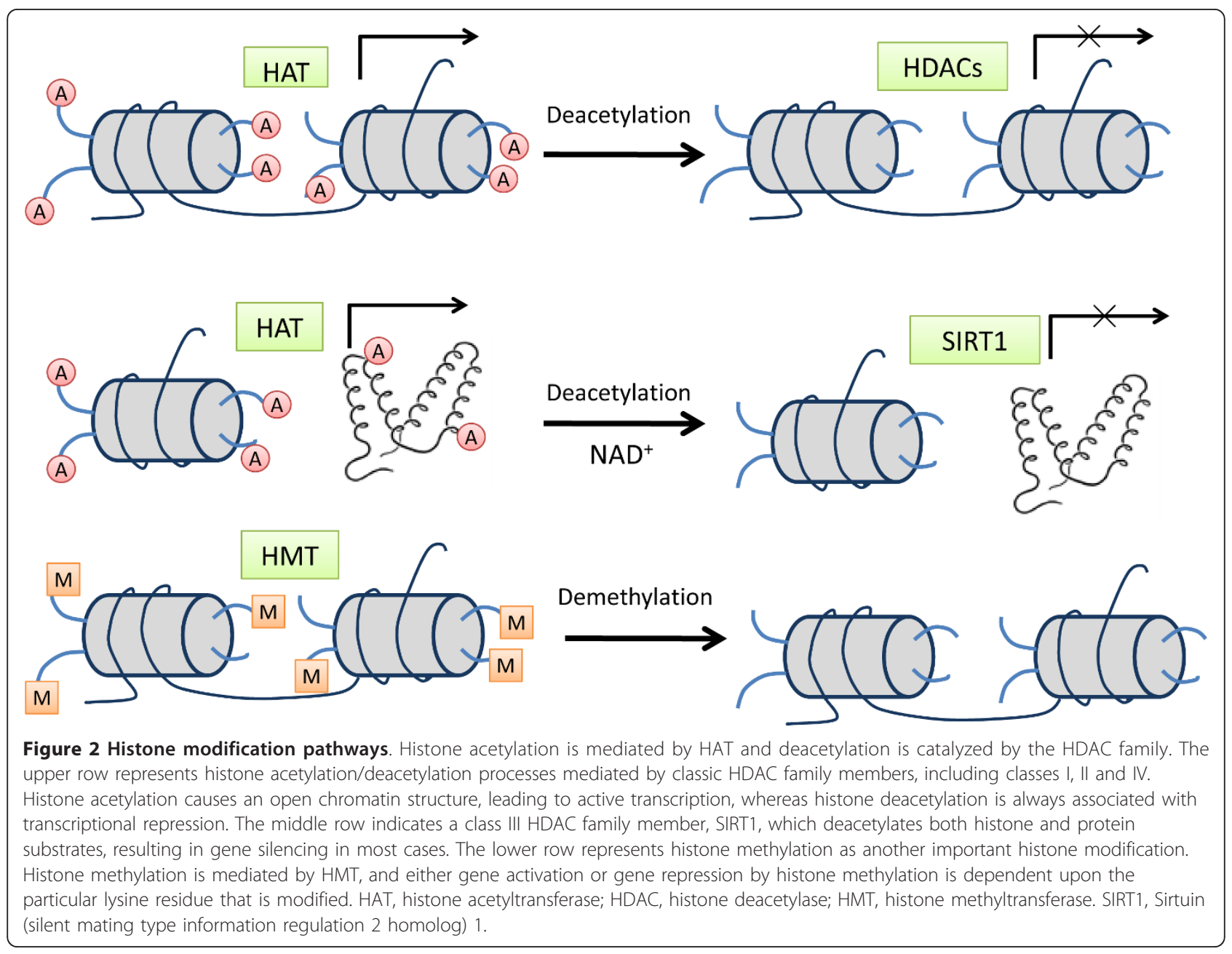


At this point, HDAC inhibitors have emerged as an exciting new class of potential anticancer agents despite little evidence pertaining to other aging-related diseases. HDAC inhibition causes acetylation of nuclear histones, leading to transcriptional activation of several key tumor-related genes, such as the cyclin-dependent kinase inhibitor $p 21^{\text {WAF1/CIP1 }}, p 53$, GATA-1 and estrogen receptor- $\alpha$, which contribute to inhibiting cancer proliferation and inducing differentiation both in vitro and in vivo [76,77]. Several HDAC inhibitors with impressive antitumor activity and relatively low toxicity, such as depsipeptide, phenylbutyrate, valproic acid and suberoylanilide hydroxamic acid, are currently undergoing phases I and II clinical trials (Table 3) [78,79]. These structurally diverse molecules with properties of HDAC inhibition support a model in which HDACs are the critical cellular targets causing chromatin instability and tumorigenesis. Bioactive dietary ingredients, such as green tea polyphenols, broccoli sprouts and soybean genistein, that have natural HDAC inhibition properties are also considered as potential cancer chemoprevention compounds which are being studied in preclinical trials (Table 3) $[62,63,80]$. This may apply to aging-associated degenerative diseases that involve similar abnormalities such as tumorigenesis, and further studies are urgently needed in this area.

\section{Sirtuin 1 and its substrates}

Several HDAC families have been identified, including class III NAD ${ }^{+}$-dependent HDACs such as Sirtuin 1. Sirtuin 1 (SIRT1) in mammals, and its orthologs in other species (Sirtuin 2 in yeast), deserves special attention due to its fundamental impact on aging regulation and CR-related lifespan extension [32-36]. The unusual enzymatic activity of SIRT1, which largely depends on NAD/NADH ratio, a key indicator for oxygen consumption, respiratory chain and metabolic rate, suggests that this protein is tightly connected to the metabolic state of cells.

The promising effect of SIRT1 in mediating CR and lifespan extension is supported by a diverse range of animal models, human subjects and even in vitro CR cellular systems [31-33,35,36,81-85]. Activation of SIRT1 is frequently seen in different animal organs affected by $\mathrm{CR}$, whereas inactivation of SIRT1 may lead to abolition of lifespan extension, suggesting a pivotal role of SIRT1 in lifespan regulation during CR. SIRT1 was initially discovered for its activation in response to CR and its role in the prolongation of lifespan in yeast [33]. This theory is solidified by findings in Drosophila, in which CR induces Sir2 activation and subsequent lifespan extension in wild-type Drosophila rather than in Sir2 mutants [33]. Further, either the Sir2 activator resveratrol or the overexpression of Sir2 leads to lifespan extension, and this longevity is not further induced by $C R$, suggesting that Sir2 is an important modulator in the regulation of aging processes.

In mammals, SIRT1-null mice do not survive longer, and most of them die during the postnatal period [86,87]. They exhibit growth retardation, multiple developmental defects and sterility, suggesting an important role of SIRT1 in early development. The role of endogenous SIRT1 in mammalian metabolic regulation has focused mainly on rodents in the context of fasting under the condition in which SIRT1 overexpression or its activity is upregulated [33-36]. Extensive studies have shown that CR induces SIRT1 expression in several tissues of mice or rats [33]. The potential mechanisms by which SIRT1 mediates CR-induced metabolic alterations and subsequent aging retardation primarily involve two aspects: first, SIRT1 activation increases stress resistance by negative regulation of proapoptotic factors such as p53 and Foxo (Table 2) [88-92]; second, SIRT1 causes a series of endocrine responses, including inhibition of adipogenesis and insulin secretion in pancreatic $\beta$ cells by regulation of key metabolism-associated genes such as peroxisome proliferator-activated receptor $\gamma$ coactivator $1 \alpha(P G C-1 \alpha)$ (Table 2) [93,94], which facilitates stress resistance and longevity (Figure 1 ).

In yeast, Sir2-mediated deacetylation of histones H3 and $\mathrm{H} 4$ and concomitant silencing of protein recruitment occurs specifically in heterochromatic regions located at extrachromosomal ribosomal DNA, telomeres and silenced mating-type loci, which benefit lifespan extension in yeast $[33,57,83,95]$. Human SIRT1 establishes and maintains chromatin silencing by preferential deacetylation at histone $\mathrm{H} 4$ lysine 16 (H4K16), but it also has been shown to deacetylate the loci of histone H3 lysine 9 (H3K9) in vitro [96] (Figure 2). Further, SIRT1 affects the levels of histone methylation by deacetylation of SUV39H1, a mammalian histone methyltransferase suppressor, leading to increased levels of the trimethylated H3K9 (H3K9Me3) modification (a chromatin repressor) [97,98].

Although classed as a HDAC, SIRT1 deacetylates a broad range of substrates, including many nonhistone substrates [33,83] (Table 2 and Figure 2). These potential substrates may include several key transcription factors and regulatory proteins that are involved in multiple pathways linked to physiological and metabolic processes that contribute to lifespan extension by CR (Table 2 and Figure 1). CR is known to exert its effect by inhibition of apoptosis, which is one of the most important regulatory mechanisms $[14,25,26]$. In this regard, p53 is notable due to its important role in the regulation of cell death and apoptosis. Downregulated p53 by SIRT1 deacetylation may affect lifespan by negatively regulating cellular apoptosis and replicative senescence processes [88-90]. Another important protein that 
influences apoptosis is Foxo. Foxo protein can be directly deacetylated by SIRT1 at lysine residues and its expression is reduced, thereby repressing Foxo-mediated apoptosis [91,92]. In addition, the DNA repair protein, Ku70, can become deacetylated by SIRT1, allowing it to inactivate the proapoptotic factor Bax, resulting in apoptosis inhibition $[99,100]$.

SIRT1 can also regulate the expression of genes that are involved in metabolic pathways. PGC- $1 \alpha$ represents the best example of these proteins in CR studies (Table 2). PGC-1 $\alpha$ is a key regulator of gluconeogenesis and fatty acid oxidation $[93,94]$. It is activated by SIRT1mediated deacetylation, which increases its ability to coactivate HNF4 $\alpha$, a transcription factor that promotes the expression of gluconeogenic genes and represses genes involved in glycolysis $[34,83]$. Therefore, SIRT1induced changes in $P G C-1 \alpha$ expression, and its downstream metabolic pathways provide a link between SIRT1 activation and the stimulation and response of metabolic systems under CR conditions.

Another key gene that can be epigenetically regulated by SIRT1 is $p 16^{I N K 4 a}$, which is a cyclin-dependent kinase inhibitor linked to cellular senescence regulation [101] (Table 2). This gene was originally identified as an important tumor suppressor gene in that it negatively regulates the cell cycle and inhibits tumor growth $[102,103]$. Current studies show that $p 16^{I N K 4 a}$ is significantly accumulated during the aging processes, indicating that $p 16^{I N K 4 a}$ can serve as a robust aging biomarker $[104,105]$. Our recent studies using human cells show that CR-activated SIRT1 can directly bind to the p16 ${ }^{I N K 4 a}$ promoter and decrease its expression through a deacetylation effect, which contributes to delaying the aging process and to lifespan extension [84]. Therefore, SIRT1, acting as a nutrition sensor, decodes the nutrition flux to ensure homeostasis or even a beneficial state such as increased longevity by reorganizing the global chromatin structure and dynamically epigenetically regulating specific genes that may involve apoptosis regulation, metabolic control and cellular senescence. Besides its pronounced roles in regulating epigenetic processes, SIRT1 has been well demonstrated to regulate genes and interact with signaling other than epigenetic control during CR, suggesting that SIRT1 may play an important role in multiaspect cross-talk between epigenetic and genetic pathways.

\section{Histone methylation}

Besides histone acetylation, histone methylation is another important histone modification that regulates gene expression [72] (Figure 2). In contrast to histone acetylation, which is always associated with open chromatin status and subsequent gene activation, differentially methylated forms of histones show unique association patterns with specific proteins that recognize these markers and thus lead to gene silencing or activating effects. Lysine residues on histones can be mono-, di- or trimethylated, and either activation or repression is dependent upon the particular lysine residue that is modified [106,107]. Our current studies have shown that histone methylation modifications such as di- or trimethylated histone $\mathrm{H} 3$ at lysine residue 3 or 4 can also regulate expression changes of key aging-related genes, including $p 16^{I N K 4 a}$ and $h T E R T$, thereby contributing to CR-induced lifespan extension of human cells (Figure 1 and Table 2) [31,84]. In other studies, researchers have reported that $p 16^{I N K 4 a}$ expression can be regulated by H3K27 trimethylation, which serves as a recruitment signal for BMI1-containing polycombrepressive complexes such as PRC1 during cellular senescence [108-110]. Therefore, the status of specific histone methylation can also serve as a transcription modulator by interacting with different transcription factors and regulate aging processes under CR conditions.

\section{Potential epigenetic treatments for aging-related diseases} The promising impact of the chromatin regulators on aging interference provides an excellent opportunity to prevent for human aging-related diseases by applying potential epigenetic drugs. An example of this is resveratrol, a natural compound found in grapes and red wine which has been demonstrated to extend lifespan in Saccharomyces cerevisiae, Caenorhabditis elegans and Drosophila through remodeling chromatin structure via mediation of SIRT1 activity [111-113]. It has been reported that resveratrol can activate SIRT1 mechanisms and mimic SIRT1-induced CR cascades, leading to increased longevity [114]. In addition to its effect on longevity, this compound is known to positively influence metabolism and reduce fat and glucose levels, resulting in increasing glucose tolerance and activation of several signaling pathways that are relevant to antistress, antioxidation and increased mitochondrial biogenesis $[115,116]$. These effects were illustrated by a current finding showing that resveratrol opposes the effects of a high-fat diet in mice [117]. Due to the toxicity of the high-fat diet, control animals in this study had early mortality, whereas resveratrol improved the health and survival rate of these mice, suggesting the important role of resveratrol in the aging process. Clinically, a total of 31 human studies involving resveratrol have been reported in the US national database http:// clinicaltrials.gov/. These studies aimed at investigating the potential role of resveratrol in diabetes, obesity, Alzheimer's disease and cancer (Table 3). These studies have revealed promising and universal effects of resveratrol by favorably altering cell proliferation, increasing cellular detoxification, protecting DNA damage, 
modulating metabolic processes and inhibiting tumorigenesis, which significantly improve human health and lead to increased human lifespan $[118,119]$.

Epigenetic therapy has shown powerful clinical potential in delaying aging and preventing aging-related diseases, especially cancer. As we have discussed previously, DNMT inhibitors, inlcuding azacitidine and decitabine, as well as HDAC inhibitors, such as depsipeptide, phenylbutyrate, valproic acid and suberoylanilide hydroxamic acid, have been widely used for cancer treatment in both experimental studies and clinical trials (Table 3). Studies have also indicated that resveratrol is a potent cancer chemopreventative agent. These findings are extremely encouraging, and future studies focusing on development of novel epigenetic drugs are urgently needed to develop effective clinical strategies to treat human aging-related diseases [120].

\section{"Epigenetic diets" that mimic the effects of caloric restriction on lifespan}

The significant epigenetic impact of CR on delaying aging and preventing aging-related diseases has motivated efforts to identify natural or synthetic compounds that mimic the effects of CR. A broad range of diets have been identified that mediate epigenetic processes, the so called "epigenetic diets," providing potential to reduce aging-associated disease incidence and possibly extending the quality and length of the human lifespan by simple consumption of such diets or extracted bioactive dietary compounds [121] (Table 3). As described previously, resveratrol represents an excellent example of an "epigenetic diet" and acts as a SIRT1 mimic that leads to increased longevity in vivo and in vitro [111-119]. Other important epigenetic diets have recently been identified, such as green tea, broccoli sprouts and soybeans, and the bioactive compounds extracted from these diets have received extensive attention due to their profound effects on cancer prevention by altering the aberrant epigenetic profile in cancer cells [62,63,80,122-125]. In particular, long-term consumption of these epigenetic diets is highly associated with a low incidence of various aging-related degenerative diseases such as cancer and cardiovascular disease, suggesting that these bioactive diets may affect aging processes by altering chromatin profiles that also occur in CR [2]. For instance, global gene expression profiling can be used to identify useful compounds correlated with biological age. Dhahbi et al. [126] developed gene expression profiling methods to discover potential pharmaceuticals capable of mimicking the effects of $\mathrm{CR}$, which may open a new avenue in the discovery of promising candidates that mimic $\mathrm{CR}$ and delay aging.

\section{Conclusions}

Epigenetically mediated changes in gene expression have become a major molecular mechanism linking CR with its potential for improving cell function and health throughout the life course, leading to delaying the aging processes and extending longevity. Understanding the epigenetic mechanisms that influence the nature of aging by CR might lead to discoveries of new clinical strategies for controlling longevity in humans. As discussed in this review, two primary epigenetic codes, DNA methylation and histone modification, play important roles in regulating chromatin structure and expression of key genes to elicit the global response to CR (Figure 1). The readily reversible feature of epigenetic alterations provides great potential for the use of specific interventions aimed at reversing epigenetic changes during aging, which may have a significant impact on delaying aging and preventing human aging-associated diseases. Although our knowledge of the role of epigenetic mechanisms in CR and its related health impact is relatively limited at present, further studies will likely provide more precise interpretation of this complicated interaction, thereby facilitating the discovery of novel approaches linking dietary or pharmaceutical interventions to human longevity. We have learned of the profound effects of SIRT1 and its mimics, such as resveratrol, in influencing aging processes, and this exciting example implies that the key to improving the quality of human life, especially for senior citizens, is in the not too distant future.

\section{Abbreviations}

bp: base pair; CR: caloric restriction; DNMT: DNA methyltransferase; HDAC: histone deacetylase; HAT: histone acetyltransferase; hTERT: human telomerase reverse transcriptase.

\section{Acknowledgements}

This work was supported by grants from the American Institute for Cancer Research (AICR), the National Cancer Institute (CA 129415 and CA 13148-31), Susan G Komen for the Cure and the American Cancer Society Award (IRG60-001-47). YL was supported by a Postdoctoral Award (PDA) sponsored by AICR and American Cancer Society Award.

\section{Author details}

'Department of Biology, University of Alabama at Birmingham, 1300 University Boulevard, Birmingham, AL 35294, USA. ${ }^{2}$ Center for Aging, University of Alabama at Birmingham, 1530 3rdAvenue South Birmingham, AL 35294, USA. ${ }^{3}$ Comprehensive Cancer Center, University of Alabama at Birmingham, Birmingham, 1802 6th Avenue South, AL 35294, USA. ${ }^{4}$ Nutrition \& Obesity Research Center, University of Alabama at Birmingham, 1675 University Boulevard, Birmingham, AL 35294, USA. ${ }^{5}$ Diabetes Comprehensive Center, University of Alabama at Birmingham, 1825 University Boulevard, Birmingham, AL 35294, USA.

\section{Authors' contributions}

$Y L$ wrote the first draft of the manuscript. All other authors contributed to the development of the manuscript. All authors read and approved the final manuscript. 


\section{Competing interests}

The authors declare that they have no competing interests.

Received: 6 May 2011 Accepted: 25 August 2011

Published: 25 August 2011

\section{References}

1. Mitchell BD, Hsueh WC, King TM, Pollin TI, Sorkin J, Agarwala R, Schäffer AA, Shuldiner AR: Heritability of life span in the Old Order Amish. Am J Med Genet 2001, 102:346-352.

2. Mathers JC: Nutritional modulation of ageing: genomic and epigenetic approaches. Mech Ageing Dev 2006, 127:584-589.

3. Sharp ZD, Richardson A: Aging and cancer: can mTOR inhibitors kill two birds with one drug? Target Oncol 2011, 6:41-51.

4. Mill J, Dempster E, Caspi A, Williams B, Moffitt T, Craig I: Evidence of monozygotic twin (MZ) discordance in methylation level at two CpG sites in the promoter region of the catechol-O-methyltransferase (COMT) gene. Am J Med Genet B Neuropsychiatr Genet 2006, 141B:421-425.

5. Oates NA, van Vliet J, Duffy DL, Kroes HY, Martin NG, Boomsma Dl, Campbell M, Coulthard MG, Whitelaw E, Chong S: Increased DNA methylation at the AXIN1 gene in monozygotic twin from a pair discordant for a caudal duplication anomaly. Am J Hum Genet 2006, 79:155-162.

6. Petronis A, Gottesman II, Kan P, Kennedy JL, Basile VS, Paterson AD, Popendikyte V: Monozygotic twins exhibit numerous epigenetic differences: clues to twin discordance? Schizophr Bull 2003, 29:169-178.

7. Poulsen P, Esteller M, Vaag A, Fraga MF: The epigenetic basis of twin discordance in age-related diseases. Pediatr Res 2007, 61:38R-42R.

8. Weindruch R, Walford RL: The Retardation of Aging and Disease by Dietary Restriction Springfield, IL: Charles C Thomas; 1988, 436.

9. Sinclair DA: Toward a theory of caloric restriction and longevity regulation. Mech Ageing Dev 2005, 126:987-1002.

10. McCay CM, Crowell MF, Maynard LA: The effect of retarded growth upon the length of life span and upon the ultimate body size. 1935. Nutrition 1989, 5:155-171.

11. Cooper TM, Mockett RJ, Sohal BH, Sohal RS, Orr WC: Effect of caloric restriction on life span of the housefly, Musca domestica. FASEB J 2004, 18:1591-1593.

12. Forster $M$, Morris $P$, Sohal $R$ : Genotype of age influence the effect of caloric intake on mortality in mice. FASEB J 2003, 17:690-692.

13. Colman RJ, Anderson RM, Johnson SC, Kastman EK, Kosmatka KJ, Beasley TM, Allison DB, Cruzen C, Simmons HA, Kemnitz JW, Weindruch R: Caloric restriction delays disease onset and mortality in rhesus monkeys. Science 2009, 325:201-204.

14. Koubova J, Guarente L: How does calorie restriction work? Genes Dev 2003, 17:313-321.

15. Richardson A: The effect of age and nutrition on protein synthesis by cells and tissues from mammals. In Handbook of Nutrition in the Aged. Edited by: Watson RR. Boca Raton, FL: CRC Press; 1985:31-48.

16. Weindruch $R$, Walford RL, Fligiel S, Guthrie D: The retardation of aging in mice by dietary restriction: Longevity, cancer, immunity and lifetime energy intake. J Nutr 1986, 116:641-654

17. Pugh TD, Oberley TD, Weindruch R: Dietary intervention at middle age: caloric restriction but not dehydroepiandrosterone sulfate increases lifespan and lifetime cancer incidence in mice. Cancer Res 1999, 59:1642-1648.

18. Hernandez-Valencia M, Patti ME: A thin phenotype is protective for impaired glucose tolerance and related to low birth weight in mice. Arch Med Res 2006, 37:813-817.

19. Ketonen J, Pilvi T, Mervaala E: Caloric restriction reverses high-fat dietinduced endothelial dysfunction and vascular superoxide production in C57BI/6 mice. Heart Vessels 2010, 25:254-262.

20. Wu P, Shen Q, Dong S, Xu Z, Tsien JZ, Hu Y: Calorie restriction ameliorates neurodegenerative phenotypes in forebrain-specific presenilin-1 and presenilin-2 double knockout mice. Neurobiol Aging 2008, 29:1502-1511.

21. Sun D, Krishnan A, Su J, Lawrence R, Zaman K, Fernandes G: Regulation of immune function by calorie restriction and cyclophosphamide treatment in lupus-prone NZB/NZW F1 mice. Cell Immunol 2004, 228:54-65.

22. Cruzen C, Colman RJ: Effects of caloric restriction on cardiovascular aging in non-human primates and humans. Clin Geriatr Med 2009, 25:733-743.
23. Roth GS, Ingram DK, Lane MA: Caloric restriction in primates and relevance to humans. Ann N Y Acad Sci 2001, 928:305-315.

24. Holloszy JO, Fontana L: Caloric restriction in humans. Exp Gerontol 2007, 42:709-712.

25. Sohal R, Weindruch R: Oxidative stress, caloric restriction, and aging Science 1996, 273:59-63.

26. Merry B: Molecular mechanisms linking calorie restriction and longevity. Int J Biochem Cell Biol 2002, 34:1340-1354.

27. Kouzarides T: Chromatin modifications and their function. Cell 2007, 128:693-705.

28. Li Y, Tollefsbol TO: Dietary effect on epigenetics during the aging process. In Epigenetics of Aging. Edited by: Tollefsbol TO. New York: Springer-Verlag; 2009:407-416.

29. Egger $G$, Liang $G$, Aparicio A, Jones P: Epigenetics in human disease and prospects for epigenetic therapy. Nature 2004, 429:457-463.

30. Hass BS, Hart RW, Lu MH, Lyn-Cook BD: Effects of caloric restriction in animals on cellular function, oncogene expression, and DNA methylation in vitro. Mutat Res 1993, 295:281-289.

31. Li Y, Liu L, Tollefsbol T: Glucose restriction can extend normal cell lifespan and impair precancerous cell growth through epigenetic control of $h$ TERT and p16 expression. FASEB J 2010, 24:1442-1453.

32. Lin SJ, Defossez PA, Guarente L: Requirement of NAD and SIR2 for lifespan extension by calorie restriction in Saccharomyces cerevisiae. Science 2000, 289:2126-2128.

33. Guarente L, Picard F: Calorie restriction: the SIR2 connection. Cell 2005, 120:473-482.

34. Leibiger IB, Berggren PO: Sirt1: a metabolic master switch that modulates lifespan. Nat Med 2006, 12:34-36.

35. Bordone L, Cohen D, Robinson A, Motta MC, van Veen E, Czopik A, Steele AD, Crowe H, Marmor S, Luo J, Gu W, Guarente L: SIRT1 transgenic mice show phenotypes resembling calorie restriction. Aging Cell 2007, 6:759-767.

36. Cohen HY, Miller C, Bitterman KJ, Wall NR, Hekking B, Kessler B, Howitz KT, Gorospe M, de Cabo R, Sinclair DA: Calorie restriction promotes mammalian cell survival by inducing the SIRT1 deacetylase. Science 2004, 305:390-392.

37. Razin A, Riggs AD: DNA methylation and gene function. Science 1980, 210:604-610.

38. Cross SH, Bird AP: CpG islands and genes. Curr Opin Genet Dev 1995, 5:309-314.

39. Callinan PA, Feinberg AP: The emerging science of epigenomics. Hum Mol Genet 2006, 15:R95-R101.

40. Li E, Beard C, Jaenisch R: Role for DNA methylation in genomic imprinting. Nature 1993, 366:362-365.

41. Li E, Beard C, Forster A, Bestor TH, Jaenisch R: DNA methylation, genomic imprinting, and mammalian development. Cold Spring Harb Symp Quant Biol 1993, 58:297-305.

42. Chan MF, Liang G, Jones PA: Relationship between transcription and DNA methylation. Curr Top Microbiol Immunol 2000, 249:75-86.

43. Goll MG, Bestor TH: Eukaryotic cytosine methyltransferases. Annu Rev Biochem 2005, 74:481-514.

44. Chen T, Tsujimoto N, Li E: The PWWP domain of Dnmt3a and Dnmt3b is required for directing DNA methylation to the major satellite repeats at pericentric heterochromatin. Mol Cell Biol 2004, 24:9048-9058.

45. Okano M, Bell DW, Haber DA, Li E: DNA methyltransferases Dnmt3a and Dnmt3b are essential for de novo methylation and mammalian development. Cell 1999, 99:247-257.

46. Okano M, Takebayashi S, Okumura K, Li E: Assignment of cytosine-5 DNA methyltransferases Dnmt3a and Dnmt3b to mouse chromosome bands 12A2-A3 and 2H1 by in situ hybridization. Cytogenet Cell Genet 1999, 86:333-334.

47. Okano M, Xie S, Li E: Cloning and characterization of a family of novel mammalian DNA (cytosine-5) methyltransferases. Nat Genet 1998, 19:219-220.

48. Knapowski J, Wieczorowska-Tobis K, Witowski J: Pathophysiology of ageing. J Physiol Pharmacol 2002, 53:135-146.

49. Issa JP, Ahuja N, Toyota M, Bronner MP, Brentnall TA: Accelerated agerelated CpG island methylation in ulcerative colitis. Cancer Res 2001, 61:3573-3577. 
50. Issa JP, Ottaviano YL, Celano P, Hamilton SR, Davidson NE, Baylin SB: Methylation of the oesterogen receptor CpG island links ageing and neoplasia in human colon. Nat Genet 1994, 7:536-540.

51. Issa JP, Vertino PM, Boehm CD, Newsham IF, Baylin SB: Switch from monoallelic to biallelic human IGF2 promoter methylation during aging and carcinogenesis. Proc Natl Acad Sci USA 1996, 93:11757-11762.

52. Singhal RP, Mays-Hoopes $L L$, Eichhorn GL: DNA methylation in aging of mice. Mech Ageing Dev 1987, 41:199-210.

53. Waki T, Tamura G, Sato M, Motoyama T: Age-related methylation of tumor suppressor and tumor-related genes: an analysis of autopsy samples. Oncogene 2003, 22:4128-4133.

54. Wilson VL, Smith RA, Ma S, Cutler RG: Genomic 5-methyldeoxycytidine decreases with age. J Biol Chem 1987, 262:9948-9951.

55. Kim TY, Lee HJ, Hwang KS, Lee M, Kim JW, Bang YJ, Kang GH: Methylation of RUNX3 in various types of human cancers and premalignant stages of gastric carcinoma. Lab Invest 2004, 84:476-484.

56. Vageuro A, Reinberg D: Calorie restriction and the exercise of chromatin. Genes Dev 2009, 23:1849-1869.

57. Muñoz-Najar U, Sedivy JM: Epigenetic control of aging. Antioxid Redox Signal 2011, 14:241-259.

58. Chouliaras L, van den Hove DL, Kenis G, Dela Cruz J, Lemmens MA, van Os J, Steinbusch HW, Schmitz C, Rutten BP: Caloric restriction attenuates age-related changes in DNA methyltransferases 3a in mouse hippocampus. Brain Behav Immun 2011, 25:616-623.

59. So AY, Jung JW, Lee S, Kim HS, Kang KS: DNA Methyltransferase controls stem cell aging by regulating BMI1 and EZH2 through microRNAs. PLOS One 2011, 6:e19503.

60. Gore SD: Combination therapy with DNA methyltransferase inhibitors in hematologic malignancies. Nat Clin Pract Oncol 2005, 2(Suppl 1):S30-S35.

61. Li Y, Tollefsbol TO: Impact on DNA methylation in cancer prevention and therapy by bioactive dietary compounds. Curr Med Chem 2010, 17:2141-2151.

62. Li Y, Yuan YY, Meeran SM, Tollefsbol TO: Synergistic epigenetic reactivation of estrogen receptor-a (ERa) by combined green tea polyphenol and histone deacetylase inhibitor in ERa-negative breast cancer cells. Mol Cancer 2010, 9:274.

63. Li Y, Liu L, Andrews LG, Tollefsbol TO: Genistein depletes telomerase activity through cross-talk between genetic and epigenetic mechanisms. Int J Cancer 2009, 125:286-296.

64. Ahima RS: Connecting obesity, aging and diabetes. Nat Med 2009, 15:996-997.

65. Larsen TM, Dalskov S, van Baak M, Jebb S, Kafatos A, Pfeiffer A, Martinez JA, Handjieva-Darlenska T, Kunesová M, Holst C, Saris WH, Astrup A: The Diet, Obesity and Genes (Diogenes) Dietary Study in eight European countries: a comprehensive design for long-term intervention. Obes Rev 2009, 11:76-91.

66. Milagro Fl, Campión J, Cordero P, Goyenechea E, Gómez-Uriz AM, Abete I, Zulet MA, Martínez JA: A dual epigenetic approach for the search of obesity biomarkers: DNA methylation in relation to diet-induced weight loss. FASEB J 2011, 25:1378-1389.

67. Bouchard L, Rabasa-Lhoret R, Faraj M, Lovoie ME, Mill J, Pérusse L, Vohl MC: Differential epigenomic and transcriptomic responses in subcutaneous adipose tissue between low and high responders to caloric restriction. Am J Clin Nutr 2010, 91:309-320.

68. Campión J, Milagro Fl, Goyenechea E, Martínez JA: TNF-a promoter methylation as a predictive biomarker for weight-loss response. Obesity (Silver Spring) 2009, 17:1293-1297.

69. Luger K, Mäder AW, Richmond RK, Sargent DF, Richmond TJ: Crystal structure of the nucleosome core particle at $2.8 \AA$ resolution. Nature 1997, 389:251-260.

70. Clayton AL, Hazzalin CA, Mahadevan LC: Enhanced histone acetylation and transcription: a dynamic perspective. Mol Cell 2006, 23:289-296.

71. de Ruijter AJ, van Gennip AH, Caron HN, Kemp S, van Kuilenburg AB: Histone deacetylases (HDACs): characterization of the classical HDAC family. Biochem J 2003, 370:737-749.

72. Strahl BD, Allis CD: The language of covalent histone modifications. Nature 2000, 403:41-45.

73. Kadonaga JT: Eukaryotic transcription: an interlaced network of transcription factors and chromatin-modifying machines. Cell 1998, 92:307-313.
74. Meyerson M, Counter CM, Eaton EN, Ellisen LW, Steiner P, Caddle SD, Ziaugra L, Beijersbergen RL, Davidoff MJ, Liu Q, Bacchetti S, Haber DA, Weinberg RA: $h E S T 2$, the punitive human telomerase catalytic subunit gene, is up-regulated in tumor cells and during immortalization. Cell 1997, 90:785-795.

75. Kanaya T, Kyo S, Takakura M, Ito H, Namiki M, Inoue M: hTERT is a critical determinant of telomerase activity in renal-cell carcinoma. Int J Cancer 1998, 78:539-543.

76. Richon VM, Sandhoff TW, Rifkind RA, Marks PA: Histone deacetylase inhibitor selectively induces p2 $1^{\text {WAF } 1}$ expression and gene-associated histone acetylation. Proc Natl Acad Sci 2000, 97:10014-10019.

77. Sambucetti LC, Fischer DD, Zabludoff S, Kwon PO, Chamberlin H, Trogani N, $\mathrm{Xu} \mathrm{H}$, Cohen D: Histone deacetylase inhibition selectively alters the activity and expression of cell cycle proteins leading to specific chromatin acetylation and antiproliferative effects. J Biol Chem 1999, 274:34940-34947.

78. Richon VM, O'Brien JP: Histone deacetylase inhibitors: a new class of potential therapeutic agents for cancer treatment. Clin Cancer Res 2002, 8:662-664.

79. Ma X, Ezzeldin HH, Diasio RB: Histone deacetylase inhibitors: current status and overview of recent clinical trials. Drugs 2009, 69:1911-1934.

80. Meeran SM, Patel SN, Tollefsbol TO: Sulforaphane causes epigenetic repression of $h T E R T$ expression in human breast cancer cell lines. PLOS One 2010, 5:e11457.

81. Kanfi Y, Peshti V, Gozlan YM, Rathaus M, Gil R, Cohen HY: Regulation of SIRT1 protein levels by nutrient availability. FEBS Lett 2008, 582:2417-2423.

82. Crujeiras AB, Parra D, Goyenechea E, Martínez JA: Sirtuin gene expression in human mononuclear cells is modulated by caloric restriction. Eur $J$ Clin Invest 2008, 38:672-678.

83. Wakeling LA, lons $\sqcup$, Ford D: Could Sirt1-mediated epigenetic effects contribute to the longevity response to dietary restriction and be mimicked by other dietary interventions? Age (Dordr) 2009, 31:327-341.

84. Li Y, Tollefsbol TO: $p 16^{\text {INK4a }}$ suppression by glucose restriction contributes to human cellular lifespan extension through Sirt1-mediated epigenetic and genetic mechanisms. PLoS One 2011, 6:e17421.

85. Haigis MC, Guarente LP: Mammalian sirtuins: emerging roles in physiology, aging, and calorie restriction. Genes Dev 2006, 20:2913-2921.

86. McBurney MW, Yang X, Jardine K, Hixon M, Boekelheide K, Webb JR, Lansdorp PM, Lemieux M: The mammalian SIR2a protein has a role in embryogenesis and gametogenesis. Mol Cell Biol 2003, 23:38-54.

87. Cheng HL, Mostoslavsky R, Saito S, Manis JP, Gu Y, Patel P, Bronson R, Appella E, Alt FW, Chua KF: Developmental defects and p53 hyperacetylation in Sir2 homolog (SIRT1)-deficient mice. Proc Natl Acad Sci USA 2003, 100:10794-10799.

88. Luo J, Nikolaev AY, Imai S, Chen D, Su F, Shiloh A, Guarente L, Gu W: Negative control of p53 by Sir2a promotes cell survival under stress. Cell 2001, 107:137-148.

89. Langley E, Pearson M, Faretta M, Bauer UM, Frye RA, Minucci S, Pelicci PG, Kouzarides T: Human sir2 deacetylases p53 and antagonizes PML/p53induced cellular senescence. EMBO J 2002, 21:2383-2396.

90. Vaziri H, Dessain SK, Ng Eaton E, Imai SI, Frye RA, Pandita TK, Guarente L, Weinberg RA: $h S I R 2^{\text {SIRT1 }}$ functions as a NAD-dependent $\mathrm{p} 53$ deacetylase. Cell 2001, 107:149-159.

91. Brunet A, Sweeney LB, Sturgill JF, Chua KF, Greer PL, Lin Y, Tran H, Ross SE, Mostoslavsky R, Cohen HY, Hu LS, Cheng HL, Jedrychowski MP, Gygi SP, Sinclair DA, Alt FW, Greenberg ME: Stress-dependent regulation of FOXO transcription factors by the sirt1 deacetylase. Science 2004, 303:2011-2015.

92. Motta MC, Divecha N, Lemieux M, Kamel C, Chen D, Gu W, Bultsma Y, McBurney MW, Guarente L: Mammalian sirt1 represses forkhead transcription factors. Cell 2004, 116:551-563.

93. Schilling MM, Oeser JK, Boustead JN, Flemming BP, O'Brien RM: Gluconeogenesis: re-evaluating the FOXO1-PGC-1a connection. Nature 2006, 443:E10-E11.

94. Vega RB, Huss JM, Kelly DP: The coactivator PGC-1 cooperates with peroxisome proliferator-activated receptor $a$ in transcriptional control of nuclear genes encoding mitochondrial fatty acid oxidation enzymes. $\mathrm{Mol}$ Cell Biol 2000, 20:1868-1876.

95. Kennedy BK, Gotta M, Sinclair DA, Mills K, McNabbs DS, Murthy M, Park SM, Laroche T, Gasser SM, Guarente L: Redistribution of silencing proteins from telomeres to the nucleolus is associated with extension of lifespan in S. cerevisiae. Cell 1997, 89:381-391. 
96. Vaquero A, Sternglanz R, Reinberg D: $N A D^{+}$-dependent deacetylation of H4 lysine 16 by class III HDACs. Oncogene 2007, 26:5505-5520.

97. Oberdoerffer P, Michan S, McVay M, Mostoslavsky R, Vann J, Park SK, Hartlerode A, Stegmuller J, Hafner A, Loerch P, Wright SM, Mills KD, Bonni A, Yankner BA, Scully R, Prolla TA, Alt FW, Sinclair DA: Sirt1 redistribution on chromatin promotes genomic stability but alters gene expression during aging. Cell 2008, 135:907-918.

98. Vaquero A, Scher M, Erdjument-Bromage H, Tempst P, Serrano L, Reinberg D: Sirt1 regulates the histone methyl-transferases SUV39H1 during heterochromatin formation. Nature 2007, 450:440-444.

99. Jeong J, Juhn K, Lee H, Kim SH, Min BH, Lee KM, Cho MH, Park GH, Lee KH: Sirt1 promotes DNA repair activity and deacetylation of Ku70. Exp Mol Med 2007, 39:8-13.

100. Cohen HY, Lavu S, Bitterman K, Hekking B, Imahiyerobo TA, Miller C, Frye R, Ploegh $H$, Kessler BM, Sinclair DA: Acetylation of the C terminus of Ku70 by CBP and PCAF controls Bax-mediated apoptosis. Mol Cell 2004, 13:627-638.

101. Wong H, Riabowol K: Differential CDK-inhibitor gene expression in aging human diploid fibroblasts. Exp Gerontol 1996, 31:311-325.

102. Gil J, Peters G: Regulation of the INK4b-ARF-INK4a tumour suppressor locus: all for one or one for all. Nat Rev Mol Cell Biol 2006, 7:667-677.

103. Krishnamurthy J, Torrice C, Ramsey MR, Kovalev Gl, Al-Regaiey K, Su L, Sharpless NE: Ink4a/Arf expression is a biomarker of aging. J Clin Invest 2004, 114:1299-1307.

104. Alcorta DA, Xiong Y, Phelps D, Hannon G, Beach D, Barrett JC: Involvement of the cyclin-dependent kinase inhibitor p16 (INK4a) in replicative senescence of normal human fibroblasts. Proc Natl Acad Sci USA 1996, 93:13742-13747.

105. Melk A, Schmidt BM, Takeuchi O, Sawitzki B, Rayner DC, Halloran PF: Expression of $\mathrm{p} 16^{\mathrm{NK} 4 \mathrm{a}}$ and other cell cycle regulator and senescence associated genes in aging human kidney. Kidney Int 2004, 65:510-520.

106. Fischle W, Wang Y, Allis CD: Histone and chromatin cross-talk. Curr Opin Cell Biol 2003, 15:172-183.

107. Kouzarides T: Histone methylation in transcriptional control. Curr Opin Genet Dev 2002, 12:198-209.

108. Bracken AP, Kleine-Kohlbrecher D, Dietrich N, Pasini D, Gargiulo G, Beekman C, Theilgaard-Mönch K, Minucci S, Porse BT, Marine JC, Hansen $\mathrm{KH}$, Helin $\mathrm{K}$ : The polycomb group proteins bind throughout the INK4A-ARF locus and are disassociated in senescent cells. Genes Dev 2007, 21:525-530.

109. Jacobs JJ, Kieboom K, Marino S, DePinho RA, van Lohuizen M: The oncogene and polycomb-group gene bmi-1 regulates cell proliferation and senescence through the ink4a locus. Nature 1999, 397:164-168.

110. Kia SK, Gorski MM, Giannakopoulos S, Verrijzer CP: SW1/SNF mediates polycomb eviction and epigenetic reprogramming of the INK4b-ARFINK4a locus. Mol Cell Biol 2008, 28:3457-3464.

111. Howitz KT, Bitterman KJ, Cohen HY, Lamming DW, Lavu S, Wood JG, Zipkin RE, Chung P, Kisielewski A, Zhang LL, Scherer B, Sinclair DA: Small molecule activators of sirtuins extend Saccharomyces cerevisiae. Nature 2003, 425:191-196

112. Wood JG, Rogina B, Lavu S, Howitz K, Helfand SL, Tatar M, Sinclair D: Sirtuin activators mimic caloric restriction and delay ageing in metazoans. Nature 2004, 430:686-689.

113. Bass TM, Weinkove D, Houthoofd K, Gems D, Partridge L: Effects of resveratrol on lifespan in Drosophila melanogaster and Caenorhabditis elegans. Mech Ageing Dev 2007, 128:546-552.

114. Barger JL, Kayo T, Vann JM, Arias EB, Wang J, Hacker TA, Wang Y, Raederstorff D, Morrow JD, Leeuwenburgh C, Allison DB, Saupe KW, Cartee GD, Weindruch R, Prolla TA: A low dose of dietary resveratrol partially mimics caloric restriction and retards aging parameters in mice. PLoS One 2008, 3:e2264.

115. Agarwal B, Baur JA: Resveratrol and life extension. Ann N Y Acad Sci 2011 , 1215:138-143.

116. Fischer-Posovszky P, Kukulus V, Tews D, Unterkircher T, Debatin KM, Fulda S, Wabitsch M: Resveratrol regulates human adipocyte number and function in a Sirt1-dependent manner. Am J Clin Nutr 2010, 92:5-15.

117. Baur JA, Pearson K, Price NL, Jamieson HA, Lerin C, Kalra A, Prabhu W, Allard JS, Lopez-Lluch G, Lewis K, Pistell PJ, Poosala S, Becker KG, Boss O, Gwinn D, Wang M, Ramaswamy S, Fishbein KW, Spencer RG, Lakatta EG, Le Couteur D, Shaw RJ, Navas P, Puigserver P, Ingram DK, de Cabo R,
Sinclair DA: Resveratrol improves health and survival of mice on a highcalorie diet. Nature 2006, 444:337-342.

118. Patel KR, Scott E, Brown VA, Gescher AJ, Steward WP, Brown K: Clinical trials of resveratrol. Ann N Y Acad Sci 2011, 1215:161-169.

119. Subramanian L, Youssef S, Bhattacharya S, Kenealey J, Polans AS, van Ginkel PR: Resveratrol: challenges in translation to the clinic: a critical discussion. Clin Cancer Res 2010, 16:5942-5948.

120. Yoo CB, Jones PA: Epigenetic therapy of cancer: past, present and future. Nat Rev Drug Discov 2006, 5:37-50.

121. Meeran SM, Ahmed A, Tollefsbol TO: Epigenetic targets of bioactive dietary components for cancer prevention and therapy. Clin Epigenetics 2010, 1:101-116.

122. Taylor CK, Levy RM, Elliott JC, Burnett BP: The effect of genistein aglycone on cancer and cancer risk: a review of in vitro, preclinical, and clinical studies. Nutr Rev 2009, 67:398-415.

123. Jayagopal V, Albertazzi P, Kilpatrick ES, Howarth EM, Jennings PE, Hepburn DA, Atkin SL: Beneficial effects of soy phytoestrogen intake in postmenopausal women with type 2 diabetes. Diabetes Care 2002, 25:1709-1714.

124. Kao YH, Chang HH, Lee MJ, Chen CL: Tea, obesity, and diabetes. Mol Nutr Food Res 2006, 50:188-210.

125. Shanafelt TD, Call TG, Zent CS, LaPlant B, Bowen DA, Roos M, Secreto CR, Ghosh AK, Kabat BF, Lee MJ, Yang CS, Jelinek DF, Erlichman C, Kay NE: Phase I trial of daily oral Polyphenon E in patients with asymptomatic Rai stage 0 to II chronic lymphocytic leukemia. J Clin Oncol 2009, 27:3808-3814.

126. Dhahbi JM, Mote PL, Fahy GM, Spindler SR: Identification of potential caloric restriction mimetics by microarray profiling. Physiol Genomics 2005, 23:343-350.

\section{Pre-publication history}

The pre-publication history for this paper can be accessed here: http://www.biomedcentral.com/1741-7015/9/98/prepub

doi:10.1186/1741-7015-9-98

Cite this article as: Li et al: Epigenetic regulation of caloric restriction in aging. BMC Medicine 2011 9:98.

\section{Submit your next manuscript to BioMed Central and take full advantage of:}

- Convenient online submission

- Thorough peer review

- No space constraints or color figure charges

- Immediate publication on acceptance

- Inclusion in PubMed, CAS, Scopus and Google Scholar

- Research which is freely available for redistribution

Submit your manuscript at www.biomedcentral.com/submit
Ciomed Central 